\title{
The Supplement of Reading
}

\section{The Disappearance of Actualization}

T is now a commonplace that the period once associated with an 1 organicist aesthetic that naturalizes the sign produced a large number of texts that are intentional in structure, "able to posit regardless of presence but, . . . unable to give a foundation to what [they posit] except as an intent of consciousness." ${ }^{1}$ This study takes as its starting point what I shall call the disappearance of narrative, dramatic, or conceptual 'actualization,' a phenomenon that results in the absence from romantic writing of embodied or achieved meaning as opposed to discarnate meaning. The problem is most obvious in the many texts that are fragments, where the written 'text' does not coincide with the hypothetical totality of the 'work.' In Coleridge's Christabel, for instance, the work is not limited to Christabel's captivation and ontological deconstruction by Geraldine. It may include a happy ending, in which the difference of Christabel from herself is annulled, as she and Sir Leoline are reconciled and Geraldine is either vanquished or saved. But this ending, sketched by Coleridge in comments to friends, is never incorporated into the text, which concludes with Christabel's being rejected by her father, and which intimates the ending only negatively, as a desire for something that might correct the present unjust state of affairs. Similarly, in Keats's Hyperion Apollo's deification is intimated at the end but is undermined by the perfunctoriness of the description and the abrupt termination of

'Paul de Man, "The Intentional Structure of the Romantic Image," The Rhetoric of Romanticism (New York: Columbia University Press, 1984), p. 6. 
the text in a series of asterisks. For Apollo undergoes no psychological development until he somewhat unconvincingly ingests the lessons of several millennia of history in five lines, as though to make us aware that his deification is not something that happens in divine history, but is a linguistic event, subject to doubt and dismantling. To bring the poem to its 'conclusion' we must leave the text, which derealizes itself, for the unheard melodies of a work 'intended' by the author.

But the disappearance of actualization is not just a feature of fragments. Blake's major prophecies present a completed action culminating in the reintegration of the divided psyche. Yet the characters are often flat and abstract, notations for characters rather than fully developed personalities. Moreover, the action, though predictable, does not unfold logically, but proceeds discontinuously through a series of imaginative leaps. As Ronald Grimes suggests, the characters "do not develop biographically." At the level of the plot "connective devices are muted. The spaces between events seem to be blank, as if inviting the reader to fill them in by himself." 2 As 'visionary forms dramatic,' to use Blake's own phrase, the prophecies require the participation of the reader if vision is to be dramatized, made concrete. Leslie Tannenbaum has discussed with reference to biblical hermeneutics this notion of the reader's actualizing the text in a "prophetic or apocalyptic theater, which ... through the communication of [the] prophecy, is relocated in the mind of the reader." 3 Much the same can be said of Prometheus Unbound, which is technically complete but does not follow the semiotics of Aristotelian drama, in which the play is the imitation of a probable action and not of an intention. Although in this case the arrival of the Promethean age is described in the text, it remains allegorical: a sequence of visionary abstractions spoken by dramatis personae who are voices and not persons. That a mythopoeic text cannot be realistic is obvious. But verisimilitude can be psychological or metaphysical as well as photographic, and this kind of verisimilitude is achieved only if we as readers stage the play in the theater of our own experience.

The disappearance of actualization is not just a feature of fictional texts. We find it also in expository prose, where continuous argument normally serves the function of plot and narrative syntax. Coleridge's Biographia Literaria, for instance, is made up of disjunctive and unsynthesized parts. Its centerpiece is a redemptive theory of imagination

2"Time and Space in Blake's Major Prophecies," in Stuart Curran and Joseph Wittreich, eds., Blake's Sublime Allegory: Essays on the "Four Zoas," "Milton," "Jerusalem" (Madison: University of Wisconsin Press, 1973), p. 64.

${ }^{3}$ Biblical Tradition in Blake's Prophecies (Princeton, N.J.: Princeton University Press, 1982), p. 48 . 
as a reconciliation of opposites that reduplicates the primal act of creation. But the link between Coleridge's aesthetics and the ten scholia from Schelling that precede it and provide its metaphysical grounding is not made in the text. Moreover, though Coleridge promises a hundredpage treatise on the imagination, the very extensiveness of which would give the theory philosophical credibility, what he provides are two elliptical paragraphs that must be fleshed out by the sympathetic reader. Characteristic of all these texts is an erosion of the reportorial, psychological, or even conceptual realism that comes from creating transitions between parts. The text becomes like the script for a film or the score for a piece of music rather than the film or music itself. It would be all too easy to conclude that much romantic literature is technically incompetent, especially since at first sight it lacks the self-consciousness about technique that might lead us to def end it as experimental. But in fact we are dealing with a series of far-reaching shifts in concepts of the location and nature of meaning, the relationship of reader to text, and finally the status of discourse itself.

Corresponding to this shift in literature itself is a shift in romantic aesthetics, from a concern with the text as a finished product that contains its own meaning to a concern with the creative and receptive processes as loci of meaning. An aesthetics of pictorialism is replaced by one based on feeling as a way of achieving 'immediacy,' making meaning present. Wallace Jackson traces through the eighteenth century the decline of the idea that literature should approximate to painting in order to summon up its subject before our eyes, and its replacement by a Burkean aesthetics of the sublime that makes us feel the experience instead of painting it for us. ${ }^{4}$ Presence comes to be located not in depiction but in an effect, something that happens in the consciousness of the reader, and correspondingly definiteness ceases to be a criterion for rhetorical success. This undoing of the model that underwrites the idea of art as a making visible ${ }^{5}$ has far-reaching implications. But for the moment it is enough to note that it aims to preserve, not to deconstruct, an aesthetics of presence. As important as the fading of pictorialism is the diminishing emphasis on genre, as a means by which the text encodes and institutionalizes what it says. Here, too, the desire is not to question, but to relocate at the level of organic form, the presence of a unitary meaning. The decline of generic criticism is matched on the

\footnotetext{
${ }^{4}$ Immediacy: The Development of a Critical Concept from Addison to Coleridge (Amsterdam: Rodopi, 1973), pp. 27-69.

${ }^{5}$ For a discussion of the relationship of pictorial and visual metaphors to a metaphysics of presence, see Allen Thiher, Words in Reflection: Modern Language Theory and Post-Modern Fiction (Chicago: University of Chicago Press, 1984), pp. 1-5.
} 
intratextual level by a diminished emphasis on the structural grammar of the text emphasized by neoclassicism. ${ }^{6}$ In chastising Milton for those breaches of decorum that make Paradise Lost and "Lycidas" fail as acts of representation, Samuel Johnson assumes that stylistic and structural integrity are versions of logical proof, and that a text marked by aesthetic dissonances is unpersuasive. But though a first-generation romantic like Coleridge continues to give some emphasis to matters of construction, such as the relationship of part to whole, he already designates as secondary imagination the capacity for formal shaping that is specifically the possession of the poet, and describes as primary imagination the originating creative perception that precedes and gives value to aesthetic structuring. We see in Coleridge the beginnings of a shift from a formalist aesthetics of craft to a phenomenological aesthetics of genius, though he stops short of rejecting structural actualization as unimportant. In this he resembles Schleiermacher, for whom psychological interpretation is primary, though grammatical interpretation is also necessary. But from here it is only a short step to a second-generation romantic like Shelley, who at times introduces a dualism between inspiration and composition that can shift the locus of meaning away altogether from the written text. Though the work behind the text is assumed to be a totality, the written text is no longer required to be an autonomous formal unit. The text may become the trace, the re-presentation, of a signified that precedes it in the creative process. Or it may become an intent of consciousness, the catalyst for a signified to be produced in the reading process. More commonly it becomes both, in a hermeneutics that sees the reading process as a corrective that recovers the separation of signifier from signified that occurs in writing.

Of interest here is the movement away from narrative realism described by Hans Frei in biblical interpretation as it develops from the seventeenth to the nineteenth century. What Frei traces, in delineating a shift from a system that codifies the rules governing the interpretation of subject matter to a hermeneutics of understanding that locates meaning in the interpretive act, is not a change in representation itself, but rather a change in the conventions of reading the Bible. But assumptions in biblical hermeneutics about the presence and location of meaning exerted a profound influence on the construction as well as the

${ }^{6}$ Eric Rothstein points out that alongside the Aristotelian aesthetics of unity there developed in the eighteenth century an aesthetics of the "non-finito": "Ideal Presence and the 'Non-Finito' in Eighteenth-Century Aesthetics," Eighteenth-Century Studies 9 (Spring 1976): 307-32. Sometimes the role of the reader seems largely prestructured by the text, but sometimes the non-finito is conceived as more genuinely open-ended. The romantic emphasis on the role of the reader obviously has its roots in this development, but it goes much further, particularly in the working out of a 'negative' hermeneutics. 
reading of secular scriptures in the romantic period. Frei describes how an increasing focus on the synoptic gospels, which are disconnected and aggregational in form, erodes the reading of biblical narrative in general as novelistic or history-like. More and more it is felt that the "cohesion of depiction with subject matter on the one hand, and of subject matter with its accessibility to present understanding on the other, requires something more than the narrative account itself." 7 Hence the "essential meaning' is deferred from the text itself to the cogito of the author, to a macrocosmic version of this cogito known as the Spirit of the Age, or to the text's 'applicative' reading.

Crucial to this development is Schleiermacher, at least as the nineteenth century culminating in Dilthey saw him. Schleiermacher's notion of a reading that takes place on two levels begins the erosion of a belief in the self-sufficiency of the text. Though the text can be studied "grammatically" - in terms of its structural and linguistic parts-it must also be studied "psychologically," through "a projection into the inner creative process," if we are to grasp the wholeness of the work. ${ }^{8}$ More importantly, Schleiermacher anticipates the Derridean sense of writing as something that threatens the identity of meaning, though he does not share in the deconstruction of a dualism that privileges parole over écriture. Psychological reading restores to a text made up of 'isolated signs' the presence that comes from making contact with the voice behind those signs. The point is that the growing emphasis of hermeneutics on the reader as coproducer of the text is initially a response to an anxiety about the self-sufficiency of the linguistic system and its subset, the textual system. This is not to say that Schleiermacher denies the presence of meaning in the text. For in the 1819 Compendium, at least, he avoids any disjunction between work and text by seeing the psychological and grammatical readings as complementary. Yet he stands on the edge of a radical shift from a concept of literature as mimesis to one of literature as a re-presentation that defers the presence of a unitary meaning. From here it is but a short step to a hermeneutics that sees this 'meaning' as present only in the writer's intention, which becomes a separable mental entity from the process of working out thoughts in language.

It would be wrong to say that this step is taken in The Defence of Poetry. For if Shelley intensifies a movement away from the text to consciousness, in the end he also reimplicates conception in expression by turning reading into a heuristic rather than hermeneutic activity. But he does seem intermittently to be mounting a hermeneutic defense of logocentr-

\footnotetext{
${ }^{7}$ Hans Frei, The Eclipse of Biblical Narrative: A Study in Eighteenth and Nineteenth Century Hermeneutics (New Haven, Conn.: Yale University Press, 1974), p. 189.

${ }^{8}$ Wilhelm Dilthey, "The Rise of Hermeneutics," trans. Fredric Jameson, New Literary History 3 (1971-72): 243-44.
} 
ism in the wake of a growing uneasiness about the stability of the sign, and it is this strand in his aesthetics, as representative of a romantic trend, that will concern us for the moment. Early in his argument Shelley proclaims a view of language as a free-standing system similar to that conceived by Saussure, in which words bear a direct relationship to thoughts, or in which the acoustic image evokes the concept signified by it. Acoustic images or "sounds" (to use Shelley's word) "have relation both between each other and towards that which they represent" (SPP, p. 484), and it is the former, the syntagmatic and paradigmatic relations among signifiers, that guarantee the coherence of the signified and its uptake by the reader. But Shelley also questions this belief that the relationship between conception and expression is unproblematic, describing the mind as a fading coal and lamenting the fracturing of the sign that occurs between inspiration and composition. Given this disjunction between signifier and signified endemic to writing, a selfpresent meaning can no longer be located in the text but must be sought in the conception that exists before it is formulated in a language that makes it different from itself. The view of the communicative process here voiced by Shelley goes far beyond Schleiermacher's: it short-circuits grammatical reading of the text by seeking a fusion with the author on a subliminal or transverbal level. Correspondingly, it also eliminates the need for structural actualization:

a word, a trait in the representation of a scene or a passion, will touch the enchanted chord, and reanimate, in those who have ever experienced these emotions, the sleeping, the cold, the buried image of the past. (SPP, p. 505)

A single sentence may be considered as a whole though it may be found in the midst of a series of unassimilated portions. (SPP, pp. $\left.4^{8} 5^{-86}\right)$

Moreover, Shelley can go far beyond the concept of reading as an actualization of the text to a concept of reading as reversal, which will be discussed later. His own readings of Dante and Milton are hermeneutic but not exegetical. Instead of explicating what is in the text, he locates the meaning of the work in an intention radically at odds with the published text, and thus inaccessible except to a purely psychological reading.

We can only touch on developments in language theory that might have led to the emphasis on the reader and to the declining importance of the grammatical level in hermeneutics itself. The radical shift after the Renaissance from an Adamic theory of language as divinely ordained to a theory of the sign as arbitrary does not unsettle signification. Instead, the earlier theory is displaced into rationalist projects for a 
universal language developed by thinkers like Leibniz and John Wilkins. Of the two factors that contribute to the stability of the sign, one is an 'atomistic' conception of language. ${ }^{9}$ The possibility that language might displace ideas does not occur because the relationship between the signifier and the signified is considered only in terms of single words, and not in terms of propositions or groups of words. The myth of referential stability is also maintained by the nature of the atoms involved. These consist of categorematic terms, nouns and adjectives that refer to substances and qualities, and not of syncategorematic terms such as particles whose function is to connect words with words. Through the emphasis on what come to be called 'matter-words' (nouns and verbs), as opposed to 'form words' ( particles and pronouns) "which express our perceptions as modified by numerous relations of Space and Time," 10 the illusion is created that language is positive, that it always names or posits something.

But Enlightenment semantics is also the scene of a more unsettling shift from the sign to the proposition as the minimal unit of discourse. This shift inaugurates an awareness that relationships between words may be complicating factors, and that ideas themselves are not simple entities but associative compounds. Stephen Land traces from a different perspective the erosion of the positivist and atomist theories of language. Thus Locke emphasizes matter-words but also concedes that there are words that name not substance but the absence of it. ${ }^{11}$ As significant is Horne Tooke, who begins The Diversions of Purley by arguing that we cannot deal with the formation of ideas without first dealing with language, and that a consideration of primarily linguistic terms like particles must therefore precede a discussion of ideational terms like verbs and nouns. His bizarre etymologies, which short-circuit this radical thesis by resolving particles into nouns and verbs so as to make them "the Name of a Thing," 12 betray a deep anxiety about the slipperiness of these words that refer only to other words, and that therefore make language a system of relational rather than positive terms. The ideational consequences of such a theory of language are suggested by Hugh Blair, who draws on associationist psychology to point out that no object

${ }^{9}$ See Hans Aarsleff, The Study of Language in England, I $780-1860$ (Minneapolis: University of Minnesota Press, 1983), p. 124; Stephen Land, From Signs to Propositions: The Concept of Form in Eighteenth-Century Semantic Theory (London: Longmans, 1974), pp. v, 2-22; Ferdinand de Saussure, Course in General Linguistics, ed. Charles Bally and Albert Sechehaye, trans. Wade Baskin (New York: McGraw-Hill, 1966), p. 113 and "Translator's Introduction," p. xvi.

${ }^{10}$ F. W. Farrar, Language and Languages (Edinburgh: Ballantyne Press, 1877), p. 107.

${ }^{11}$ Land, From Signs to Propositions, pp. 184-85. Such words also include negative nouns like 'silence,' which represent the absence of something.

${ }^{12}$ Horne Tooke, The Diversions of Purley (London: Thomas Tegg, 1840), pp. 15-25, 631 . 
"presents itself to our view isolé . . but always occurs as somehow related to other objects; going before them, or following them . . . ; resembling them or opposed to them." 13

There is evidence that in the nineteenth century concepts of language move in an increasingly diacritical direction. Thus F. W. Farrar, who draws on a wide range of European sources, argues that words "cannot express an intrinsic meaning. . . . They are nothing more ... than organizations of relations." 14 According to Land, the shift from signs to propositions and the related displacement of interest from nouns to connectives results in a protostructuralist theory of language in which its relational nature determines rather than disseminates meaning. But often, as we will see in the case of Shelley and Blake, it is in these terms that connect words with each other or stand in place of other words that a precise referent seems to vanish. Once a fixed meaning can no longer be located in individual word-atoms considered as signs of things or as reproducing the logical status of referents, the question arises of how we grasp what is not quite in the words but between or behind them. It is here that semantics rejoins the recuperative project of hermeneutics. Tooke uses the grammatical term 'subaudition' to explain how we construct a meaning not present in the particular word or phrase. Subaudition accounts for abbreviation in grammatical constructions and describes a process by which the listener restores something not explicitly voiced so as to clarify the construction or the etymology. ${ }^{15}$ Much later Michel Bréal in his Semantics focuses on the problem of 'polysemia' and returns to the concept of subaudition to posit an "interior syntax" that allows the listener to fill in "what is missing" and to clarify "the uncertainties of language." 16

Subaudition is the grammatical equivalent of psychological reading at the level of larger interpretive units. But it is also apparent that both are

${ }^{13}$ Lectures on Rhetoric and Belles Lettres, 3 vols. (London: Strahan and Cadell, 1785 ), I, 354.

${ }^{14}$ An Essay on the Origin of Language (London: John Murray, 1860), p. 39. See also Language and Languages, pp. 251-54. See also Rousseau's distinction between colors, which have an "independent" meaning, and sounds, which have meaning only in relation to each other: Essai sur l'origine des langues, ed. Charles Porset (Bordeaux: G. Ducros, 1968), p. 173.

${ }^{15}$ Aarsleff, The Study of Language, p. 64.

${ }^{16}$ Aarsleff, From Locke to Saussure: Essays on the Study of Language and Intellectual History (Minneapolis: University of Minnesota Press, 1982), pp. 320, 387-88; Michel Bréal, Semantics: Studies in the Science of Meaning, trans. Mrs. Henry Cust (19oo; rpt. New York: Dover, 1974), pp. 139-41, 106. Aarsleff compares Bréal's notion of going behind the word to the thought and the similar attempt by Cartesian linguistics to go beyond the surface grammar to the deep structure (From Locke to Saussure, p. 388). But the differences between Bréal's semantics and the tradition that extends from the Port-Royal philosophical grammar to Chomskian linguistics are equally instructive. On this tradition see Noam Chomsky, Cartesian Linguistics: A Chapter in the History of Rationalist Thought (New York: Harper and Row, 1966), pp. 29, 31-33, 35, 44. In the latter the changes that occur when deep structure is converted to surface structure are syntactic rather than semantic: surface structure is a 
highly problematical concepts. The rise of hermeneutics is the beginning of a massive but still unacknowledged change in romantic concepts of discourse. For one cannot shift the location of meaning to the reading process without also changing the very status of meaning as a fixed essence that does not vary between readers. David Simpson points to a tendency in romantic aesthetics toward the "disestablishment of the text as an authority and the stressing of its function as a heuristic stimulus." 17 But the fact that hermeneutics inaugurates the disestablishment of authoritative meaning was not recognized by its practitioners. Indeed, they turned to hermeneutics because of its apparent logocentrism: its origins in biblical interpretation, which also committed it to preserve the authority of various secular scriptures. Yet the contradictions in the hermeneutic concepts of author and reader will eventually lead to the dismantling of its fervent logocentrism. While denying the authority of the text and its classic or historically invariable status, romantic hermeneuticists of ten conceive of the author as a grounding center. Equally problematical is the role assigned to the reader. For hermeneutics grants the reader as producer of the text a large degree of autonomy from the letter of the text, while initially requiring a fidelity to its spirit that takes away the very liberty conferred on the reader.

\section{Varieties of Hermeneutic Reading}

The degree to which the construction of romantic texts displaces their 'meaning' from the mimetic to the hermeneutic level will obviously vary. At the simplest level there are poems in which the parts of the whole are present in the text but unsynthesized. Blake's Marriage of Heaven and $\mathrm{Hell}$, for instance, consists of disparate sections of parable and proposition that must be dynamically connected by its readers if such a marriage is to be accomplished in our consciousness. The concluding "Song of Liberty" provides, as the rest of the text does not, a narrative sequence for this process. But it consists of twenty numbered sentences that indicate the stages of an action without actually embodying it. Harold Bloom speculates that each sentence was meant to be a caption for an engrav-

reordering of deep structure but is not more ambiguous than the former (cf. Chomsky, p. 49). By contrast, for Bréal grammar has become ambiguous and inadequate: "it is an undoubted fact that language designates things in an incomplete and inaccurate manner" (Bréal, Semantics, p. 171).

${ }^{17}$ Irony and Authority in Romantic Poetry (Totowa, N.J.: Rowman and Littlefield, 1979), p. 25. Simpson conflates hermeneutic and heuristic concepts of the text-reader relationship. This conflation exists in nineteenth-century hermeneutic theory, but I see romantic writers as gradually discovering the distinctness of the two. 
ing. ${ }^{18}$ As the text stands, however, the links between them are omitted, as are the plates that might concretize them and bring them to life, so that the responsibility for making the shorthand of the text into an imitation of an action rests with the reader.

The disappearance of actualization may occur at a structural level through the omission of links in the narrative syntax of the text. But this process of derealization may also occur at the level of smaller semantic units. Donald Davie has suggested that the language of Wordsworth's Prelude, which hovers between the concrete and the abstract, is made up of words that signify rather than embody their meaning: 'fiduciary' symbols that, like coins as values of monetary exchange, possess their value as a result of a social contract. Wordsworth's words, he argues, "will carry the reader only so long as he does not loiter . . . [they] have meaning so long as we trust them." 19 What is at issue here is a loosening of the strict denotative bond between sound and sense that exists in similarly philosophic works like Pope's Essay on Man. In Wordsworth the acoustic image, as Davie sees it, becomes a stimulus to us to produce through sympathetic understanding a signified that we half create and half perceive. Here, as in The Marriage, the elements of a completed meaning are present in the text, but the reader must participate in the process of actualizing them, sometimes by reading through or around certain aporias in the text that might otherwise deconstruct it.

A more complex case is Blake's Songs, where it is not simply the animation but also the organization of the parts into a whole that is left unaccomplished. In the Songs the exact sequence of the poems is not specified. It is clear enough that we are meant to do more than simply proceed from Innocence to Experience, but where we set a terminus to the endlessly complex process of intertextualizing poems and states of mind is less clear. Blake himself, in ending different editions of the Songs with different poems, seems to have produced the telos of the textual process in more than one way. A traditionally hermeneutic reading, however, would reconstruct 'Blake's' intention from such larger contexts as the author's oeuvre and the spirit of the age, combining the poems dialectically so as to generate from the contraries of innocence and experience a progression in the reader's consciousness toward the state of organized innocence.

The texts so far discussed are all special cases in that they are not simply dependent on the reader to interpret them but also to supply something that they do not contain. There is no poem in the Songs that

${ }^{18}$ Blake's Apocalypse: A Study in Poetic Argument (1963; rpt. Ithaca, N.Y.: Cornell University Press, 1970), p. 96.

${ }^{19}$ Articulate Energy (London: Routledge and Kegan Paul, 1955), pp. 106-7. 
actually consolidates the state of organized innocence, for the Lyca poems celebrate it as fantasy and therefore as an abstraction from reality. But in all the cases considered the components of a completed meaning are present in the text. It is simply that the meaning is not produced in the text but by the reader and is therefore accessible only through psychological reading, or through applicative reading, in which meaning is validated through our application of the text to our own lives. Much the same is true of the expository prose so far considered. What happens in Biographia Literaria is not that the goal of Coleridge's argument is unclear. Rather, he leaves his argument rhetorically unactualized and concludes with a merely embryonic definition of the imagination, lest the insertion of self into language, the process of elaboration and demonstration, turn out to be a process of dismantling. The onus is then on the imaginative reader to restore the unity of the work. But a different case arises when the terminus of the work is quite literally absent from the text and the reader must reconstruct not something that is partially present but something that is not there at all.

An initial example of such a work is Christabel, where the projected ending not only does not follow from the events that lead up to it, but also does not follow the rest of the text. There is a cryptic conclusion to part II that may, if we interpret it allegorically, tell us that the wrath of Christabel's father is the reverse side of love, and that his apparent rejection of her is the other side of a coin that the imaginative reader can turn over to reveal the happy ending. This conclusion stands in place of the happy ending Coleridge sketches elsewhere, and re-presents it as a deferred presence. But it is tacked on in such a way that it can be no more than a sign, a token of faith. Moreover, it does not function in the same way as the ending of Keats's Hyperion, where the text at least points to the work; rather, it stands in place of comments about a happy ending that Coleridge made to friends and is a supplement to an absent signifier that can be restored only if the actual ending of the narrative is disregarded or reversed. It is a signifier that stands in place of a further signifier and not even of a signified.

If the first group of texts calls for a synthesising hermeneutics, this second group requires a much more radical hermeneutics of reversal, in which the positive essence of the work must be grasped across the barrier of the text's negativity, and in which the reading process does not simply complete the creative process but compensates for the deconstructive momentum of the latter. The model for a hermeneutics of reversal can be found in the later work of Schelling, and more problematically, in Kierkegaard's The Concept of Irony, both of which are discussed in the next chapter. What is interesting for our purposes is that Schelling employs literary terms such as 'irony' to interpret the text of Being, 
which allows us to reverse his procedure and to see his ontology as a hermeneutic. Arguing that every element contains the seed of its opposite, he sees the created world as characterized by envelopment and irony. In other words, its apparent meaning envelops a deeper and quite opposite meaning; its signs must be read ironically, as expressing a demonic or inverted world in which God, through his "art of dissimulation or irony displays the reverse of that which he genuinely wills" $(A W, \mathrm{p}$. 77). A poem like Christabel has already introduced the negative stage of the rhetoric of envelopment in showing how the apparently 'good' Christabel bears the psychic trace of the 'bad' Geraldine. Within a hermeneutics of reversal, the reader is asked to bring to light the contrary envelopment of good within evil by believing that the good Christabel is still present within the defeated Christabel, and that God, for reasons unknown, is temporarily displaying the reverse of what he genuinely wills.

One may well ask how the reader is to reconstruct the hidden meaning of a work if that 'meaning' is not even partially present in the text. One answer is that it is present, but so carefully concealed as to be evident only to the discerning reader. A second answer is that it is made explicit somewhere else in the canon. The same process of inference from whole to part which allows us to read through the aporias in an individual work must be seen as operating between the authorial canon as a whole and the parts of that canon composed by individual texts. In other words, we are asked to break the hermeneutic circle at the level of the oeuvre, projecting into the individual text a set of meanings that it does not have in isolation, and perhaps even reversing the reading that emerges when the text is made its own context. Schelling's phenomenology allows for the placing of irony as a moment in the unfolding of the cultural unconscious. It allows for the presence of the positive within the negative, if we imaginatively complete the process by which the seed becomes the plant. Similarly, the hermeneutic notion of a canon, whether completed, as in the case of Blake, or hypothetical, as in the case of Coleridge, permits a reversal of the textual reading by allowing us insight into a later stage in the phenomenology of the author's spirit.

Canonical reading is not the only strategy for interpretation implicit in romantic theory and practice. Because in Shelley's phrase "a word," or a "trait" is sufficient to reanimate a narrative archetype (SPP, p. 505), the reader may complete a text by referring it to a completed parallel in literature or myth. Such a strategy informs Keats's Endymion, where the repeated evocation of the "old tale" that the modern redaction is not quite able to imitate serves as a figure of reading that inscribes the narrator's desire for a certain kind of ending. A similar strategy informs Hyperion, where a parallel between the first three books of Paradise Lost 
and the three books of Keats's poem supplies a movement from light to darkness not clearly present in the text itself. A variant of this strategy is behind Blake's statement that the Bible is "the great code of art," a statement that calls for typological reading of authorial canons. Yet another strategy for psychological reading that informs the rhetorical construction of romantic texts involves supplementing what is in the text with other transcripts of the author's 'intentions' (notebooks, letters, lectures), with sympathetic awareness of the author's life and the goals to which it is oriented, or with knowledge of what was thought in the author's circle. The process of understanding texts by bringing them to life is a feature of the hermeneutics that subsumes philological scholarship in the nineteenth century. But more important, it is part of the rhetoric of romantic texts, which of ten place themselves in "life" by referring to actual people and to the time, place, and circumstances of composition, so as to invite the reader to identify with the writer.

An example of how canonical reading can be used to facilitate a hermeneutics of reversal is The (First) Book of Urizen by Blake, or more properly, the critical treatment it has received. ${ }^{20}$ On the face of it the poem presents the phenomenology of spirit, both individual and cosmic, as a series of degenerative cycles and thus seems to decenter the Blakean journey toward Jerusalem. But critics are of ten able to give the poem a positive meaning as an antithetical moment in the dialectic of Blake's canon. Crucial to a negative hermeneutics that 'saves' the positive meaning of the text would be an analysis of the rhetoric of parody and satire as presenting inverted worlds whose very grotesqueness motivates the reader to reverse them. But equally important would be a redemptive analogy between the corpus of Blake's texts and the biblical canon, which similarly contains infernal moments. The readings sketched here are of course considerably more complex than the other 'hermeneutic' readings off ered earlier and involve the reader in a kind of somersault rather than a simple reconstruction or completion. The psychological reading here does not so much anchor itself in the grammatical reading as it effects a canceling and sublation of the latter. The canonical reading of Urizen is certainly not impossible. But as will become apparent when the poem is discussed in greater detail, like all traditionally hermeneutic readings, it is problematical. One difficulty is that Urizen is by no means a purely parodic figure, an Ubu Roi, but is of ten dispiritingly sublime. The Urizenic order can at times seem inevitable, and we cannot always persuade ourselves that it is inverse as well as perverse. Moreover, the lapidary structure of the poem, which consists of discrete chapters subdivided into disjunct verses between which the reader must construct

${ }^{20}$ Cf. Tannenbaum, Biblical Tradition in Blake's Prophecies, pp. 201-24. 
causal and chronological bridges, makes the text radically ambiguous. The metaphysical narrative that we construct if we see the entry of selfconsciousness into the world as error rather than self-discovery is already a discourse in a text that has no story. If readers center the poem's significance in the manner suggested, it is because they know (or think they know) from other works that in Blake's mythology Urizen is a villain and not an antihero. But readers who recognize the repressive critical function of concepts such as author, canon, and system used to homogenize the text may well choose not to follow the hermeneutic reading suggested. Indeed, Blake himself may thematize the inconclusiveness of the hermeneutic reading through Fuzon, who represents the energy that breaks out of the Urizenic prisonhouse in which readers who read logically, literally, and therefore pessimistically are trapped.,

\section{Hermeneutic and Heuristic Reading}

It should be clear by now that any attempt to explain the disappearance of actualization by a hermeneutics that locates meaning outside the written text is fraught with problems. The absence of a self-identical meaning results partly from a feeling that language is not product but process, or to quote Wilhelm von Humboldt, "Language is not a work (ergon) but an activity (energeia)." Both Humboldt and Schleiermacher argue that because written language is an "incomplete, mummified depository," the reader must be dynamically involved in the generation of meaning if literature is to become a psychological as well as a semiological event. ${ }^{21}$ But the absence of actualized meaning also results from a disjunction between signifier and signified in the text of the social and human psyche, a feeling that the meaning of events in the world is not given, and thus that literary discourse can no longer codify meaning but can only be a heuristic stimulus to its production. In its initial stages romantic hermeneutics both initiates and masks this crucial change in the status of discourse. Because it sees literature as a productivity rather than a product, it inevitably sees literary meaning as implicated in larger processes such as communication and history. But at the same time traditional romantic hermeneutics neutralizes this recognition by making reading a process but positing as the goal of this process a product, a fixed center behind the text called the 'work.'

The argument for the importance of traditional hermeneutics to an understanding of romanticism is not based on any assumption that it

${ }^{21}$ Wilhelm von Humboldt, Humanist without Portfolio, trans. Marianne Cowan (Detroit: Wayne State University Press, 1963), p. 280. 
WORD $\leftrightarrow$ THING

Figure $\mathbf{I}$.

provides a key to the texts, but rather on its presence at the site of certain formative tensions in romantic views of discourse. The disappearance of actualization can very well lead to our viewing the text as the locus for a deconstruction of meaning. For in its displacement of meaning from language to consciousness, hermeneutics recognizes that the relationship between signifier and signified is problematical. But by seeing this relationship as something that has psychological and interpersonal as well as semiological dimensions, it also attempts to forestall the poststructuralist fracturing of the sign. The crucial historical role of hermeneutics as conserver of a continued though problematical logocentric impulse in romanticism will be apparent if we consider the different possible views of the linguistic sign. Theories of language that posit an innate resemblance between words and things, such as the seventeenthcentury ontotheological theories of language as something given by God to Adam, allow for a direct correspondence between word and thing that we can express through the dyad in Figure 1. But the moment language is conceived of as a conventional system in which signification involves a relationship between acoustic image and concept rather than word and thing, the correspondence becomes more problematical. Structuralist theories of language continue to see the linguistic system as a freestanding whole in which the correspondence between signifier and signified can be expressed in terms of the dyad in Figure 2. This arbitrary correspondence in the individual semantic atom is subtended diacritically by systematic syntagmatic and paradigmatic relations between elements of the system. In considering the problem of meaning in both traditional hermeneutics and poststructuralism, however, it is useful to think in terms of the tetrad in Figure 3. For many nineteenth-century hermeneuticists, writing disrupts the bond between signifier and signified that exists before expression. The reader, however, is able to mediate between language and actuality, and to restore this link. We do so by penetrating into the consciousness of a centering subject, the author, and thus guaranteeing the sign as intention though not as reference. The hermeneutic circuit is then completed as in Figure 4 through a reading that is application as well as divination: the reader transforms intention into reference, and reunites the signifier and signified by an

\section{ACOUSTIC IMAGE $\leftrightarrow$ CONCEPT}


SIGNIFYING SUBJECT

SIGNIFIER

SIGNIFIED

\section{READER/RECEIVER}

Figure 3.

act of emotional commitment. In poststructuralism, by contrast, the links between all elements of the tetrad are disrupted, and thus it becomes impossible to restore the bond between signifier and signified. It is precisely this radical fracturing of the work as sign that traditional hermeneutics recontains by introducing the subject (reader and author) into the impersonal network of language and making signification a matter of communication between persons as well as of correspondence between words and referents.

Yet such readings are undermined by the fact that they compensate for the supplementarity of writing by substituting for it what can fairly be called the supplement of reading: writing, which stood in place of an absent signified, is now replaced by reading, which stands in place of writing. Hence the relevance of traditional hermeneutics to romantic texts can only be a corrective one: it reminds us that literature is the interaction of text and reader, and not simply the interplay of text and subtext. But this interaction, as was apparent in the case of "The Eolian Harp," is much more complicated than a hermeneutic reading will allow. If we attempt such readings, it is because the currency and influence of a traditional hermeneutic in the romantic period means that they are of-

SIGNIFYING SUBJECT/AUTHOR

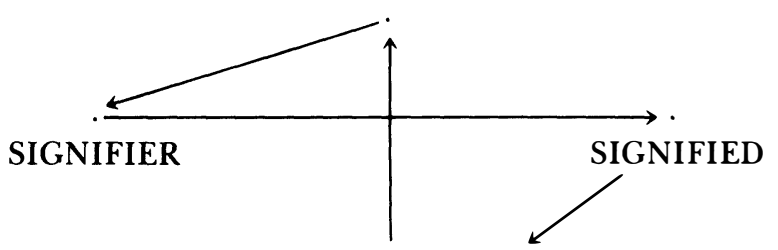

READER/RECEIVER 
ten suggested in the text or in the canon. As Roland Barthes indicates, however, the author enters the text as a "guest ... inscribed ... like one of his own characters, figured in the carpet."22 Similarly, the hermeneutic recovery of authorial 'intention' must also be seen as a guest in the text, possessed of no more authority than other possible readings. And indeed, the hermeneutic tradition itself develops toward such a recognition, as the notions of intention and authority work themselves out in the texts of Kierkegaard and of Schleiermacher himself.

The rise of hermeneutics speaks for a romantic belief that texts, even if they are intentional in structure, are productively engaged with something outside the prisonhouse of language. But while the disappearance of actualization does not make the text into the site for an erasure of meaning, it also does not allow for a reinstallation of the verbal icon in the inner temple of the work. Implicitly or explicitly, romantic texts function as heuristic stimuli for the production of meanings that are historically and personally variable. For texts that project an ideal reader or inscribe within themselves a model of the reading that will make them complete jeopardize their own closure by making the sympathetic reading a figure within the text. Thus, increasingly there are also texts that seem designed as what Barthes calls 'writerly' texts, in which the reader becomes in some sense a writer of the text. ${ }^{23}$ The distinction between the two kinds of texts is easier to maintain in theory than in practice. Often the second kind will suggest its own authorized reading, but as a construction of desire that nevertheless does constrain the free play of reading. Not surprisingly, the overlap between hermeneutic and heuristic texts is more likely to occur in texts that do not simply imply a model of reading through genre and mode, or include figures of reading, but in those that thematize the problem of reading more extensively in a scene of reading or through numerous (and significantly different) scenes of reading.

Coleridge's conversation poems provide an instance of the poem that is designed as traditionally hermeneutic. At the other extreme, some of Blake's early texts exemplify what Umberto Eco calls "works in movement": a designation more specific than the larger category of the "open work." Works in movement do not simply elicit the "theoretical, mental collaboration" of the reader in interpreting "a product which has already been organised in its structural entirety": they consist of "unplanned or physically incomplete structural units," which call on the reader to do all or part of the organizing. ${ }^{24}$ Characteristic of Blake's early texts is their

22Image, Music, Text, trans. Stephen Heath (New York: Hill and Wang, 1977), p. 161. ${ }^{23} \mathrm{~S} / Z$, trans. Richard Miller (New York: Hill and Wang, 1974), pp. 3-4.

${ }^{24}$ The Role of the Reader: Explorations in the Semiotics of Texts (Bloomington: Indiana Uni- 
AUTHOR

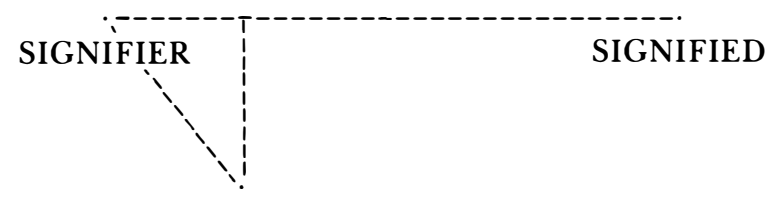

READER

Figure 5 .

paratactic organization in terms of disjunct units that must be synthesized by the reader, or in terms of fractured prosodic and thematic planes that make the text, in Kristeva's words, "an intersection of textual surfaces rather than a point (a fixed meaning)," "a dialogue among several writings." 25 Leopold Damrosch has summed up this tendency in describing the Blakean text as kaleidoscopic, composed of "transferrable parts," and thus resistant to a holistic analysis deriving from notions of organic form. ${ }^{26}$ The result is that these early texts do not 'contain' their meaning. They are decentered texts, but with consequences that are productive and generative. Traditionally, Blake criticism (not without encouragement from Blake himself) has taken the early works and read them in the light of the later system. This reading of the canon, however, is a fiction developed within the canon itself. For Blake's habit of intertextualizing poems (as in the addition of the Songs of Experience to the Songs of Innocence) and of reprocessing his own material by returning to the same nexus of events and characters in successive prophecies means that he himself constantly unseals the work he has written and makes it into a text. Blake's texts represent a kind of text we have not so far discussed, which functions without the protection of a theory of meaning that guarantees the individual reader's production of meaning will also be a reproduction of something encoded by the author. As Figure 5 indicates, the heuristic text renounces the power to codify meaning associated with the authority of the author, but it also retains the power to refer to and affect reality, with the result that text and reader mutually make and remake each other.

versity Press, 1984), p. $5^{6}$. I obviously do not agree with Eco's view that open works (and the aesthetics that legitimizes them) do not exist before the late nineteenth century (p. 53).

${ }^{25}$ Julia Kristeva, Desire in Language, trans. Leon Roudiez (New York: Columbia University Press, 1980), p. $\mathbf{6}_{5}$.

${ }^{26}$ Symbol and Truth in Blake's Myth (Princeton, N.J.: Princeton University Press, 1980), pp. 349-5o. 
A heuristic concept of discourse shares with a hermeneutic one the assumption that literature has an affective power, but it also renounces the closure of the sign to which the latter remains committed. Reading can no longer be conceived as the reconstruction of an original meaning but must be seen as the production of a new meaning. Consequently, the signifying complex constructed by the reader out of the text-the discourse of reception-cannot be related back to a transcendental signified in the author's psyche, and remains an intent of consciousness. What we have hitherto called the 'work' is of course of the same order as this complex constructed out of the text, so that the heuristic concept of discourse collapses the distinction between work and text. Reading does indeed engender signification: in the act of reading signifier and signified are fused through a third element-involvement, or what Ricoeur calls "appropriation" (Aneignung). ${ }^{27}$ But this fusion does not occur through a reading that reconstructs the meaning of the text and thus institutionalizes itself by making the work into a signified and then into a book. Early romantic hermeneutics assumes three key elements that we shall call 'text,' 'work,' and 'book.' Using the text (which is understood through grammatical reading) as a pre-text, the reader through divination generates the work. The text may stand in relation to the work as a positive transparency (as is the case in a reconstructive hermeneutics), or as a negative transparency, a displacement (as is the case in antithetical hermeneutics). But the point is that the usefulness of the text ceases as soon as the work has been constructed from it. The work, however, is still no more than an intent of consciousness, until the reader has confirmed it as reference by relating the signifying system of the work to a transcendental signified in the reader's psyche. At this point, through a series of readings leading from the grammatical through the psychological to the applicative, we have moved from the text, through the work, to the book. The book is something public: it can be placed in libraries and prescribed in courses. Although the work exists only in the consciousness of the author, the book is something that cannot be created without the existence of the reader, hence the pivotal place of the reader in hermeneutics.

The explicitly heuristic text, as we shall see, is not reducible to a single formula. One way of describing it is to say that it presents reading as performative rather than constative: although it does not legitimize reading as the repetition of an anterior meaning, it assumes that the very performance of reading will authorize the meaning so constructed. The term 'performative' suggests a mode of understanding that temporarily

27Paul Ricoeur, Hermeneutics and the Human Sciences, ed. and trans. John B. Thompson (New York: Cambridge University Press, 1981), pp. 182-93. 
brackets the self-reflexive: in other words, such reading, in which the heart becomes its own oracle, constructs a unified if hypothetical meaning out of a disjunctive text through a will-to-power. Thus we may expect to find in the spectrum of texts to be considered a certain number of 'performative' texts, Blake's Marriage and Shelley's Prometheus Unbound being examples. Unlike 'hermeneutic' texts, these texts are highly self-conscious and present themselves as linguistic entities. They assume that they exist only as they are performed and may go so far as to inscribe a particularly desirable performance, but only as a fiction. Paul de Man has questioned the legitimacy of the performative as a category in asking whether "the language of truth (episteme)" can convincingly "be replaced by a language of persuasion (doxa)" as a means of restoring to literature the power to give a foundation to what it posits. Rhetoric, he suggests, "considered as persuasion . . . is performative but when considered as a system of tropes, it deconstructs its own performance." 28 But the performative text makes us aware that the problem can also be seen the other way round. Considered as a system of tropes, it suggests, rhetoric may be self-consuming, but considered as persuasion it can still be performative.

Nevertheless, there is a sense in which performative reading is no more than a historicized version of hermeneutic reading, similar to the latter in deferring the responsibility for constituting a unified meaning from the text to the reader, but different in that it locates its authority in a culturally variable reading community rather than in an origin. While conceding that a text can be performed in different ways, it segregates these performances from each other, so as to make each reading internally consistent and thus persuasive. But it is not really clear that each reading can really remain untroubled by others, in a joyous pluralism of complementary performances or in a competing economy of cultural free enterprise. Thus we can also expect to find among heuristic texts a certain number that thematize reading as a simultaneous construction and unraveling of meaning, so as to recognize that it may be implicated in the same pressures as writing. As extended scenes of reading, poems like Shelley's Triumph of Life explore how reading complicates and disseminates as well as performs meaning. Such a view of reading may sound very similar to the one taken by de Man. But as we shall see, the heuristic text still allows us to take a phenomenological view of speech acts as having the form (if not the content) of an understanding, of a movement behind appearances to their ground. Put very simply, there is a difference between reading a poem as writing, and reading it as ad-

${ }^{28}$ Allegories of Reading: Figural Language in Rousseau, Nietzsche, Rilke, and Proust (New Haven, Conn.: Yale University Press, 1979), pp. 130-31. 
dressed to a reader. The latter brings into play the desire to understand, or what Ricoeur calls "appropriation." As my constant blurring of the line between heuristic reading and heuristic texts suggests, this difference is not simply an interpretive convention but is grounded in the texts themselves. Ricoeur's distinction between language and discourse is once again useful. The heuristic text requires to be read as discourse, as something addressed by an author to a reader within a temporal framework. The increasing focus on the reader, then, is at the center of an important shift in romantic concepts of the status of literature: of reading and writing and the stability of the meaning they convey. Clearly, there are problems in the attempt-whether hermeneutic or heuristicto recover the authority of the sign through the supplement of reading. But we cannot dismiss as a futile postponement of semiotic nihilism the sense that the problem of the text's difference from itself must be reconceived in terms of the reader. Writing is already thought of as an alienated medium that exists in the gap between signifier and signified. But reading in the romantic period is still to some extent conceived as an action, hence a medium in which the fracturing of the sign can be momentarily overcome, through a desire that creates understandings even if it does not uncover truths. 